\section{ADMA}

Jurnal Pengabdian dan Pemberdayaan Masyarakat

\title{
Pendampingan Proses Pembuatan Soal Berbasis Computational Thinking pada Guru Tingkat SD dan SMP di Kecamatan Sakra, Kabupaten Lombok Timur
}

\author{
Ni Ketut Sriwinarti ${ }^{1}$, Apriani $^{2}$, Diah Supatmiwati ${ }^{3}$, Kartarina $^{4}$, Ismarmiaty ${ }^{5}$ \\ sriwinarti@universitasbumigora.ac.id ${ }^{1}$, apriani@universitasbumigora.ac.id ${ }^{2}$, \\ diah.supatmiwati@universitasbumigora.ac.id ${ }^{3}$, \\ kartarina@universitasbumigora.ac.id ${ }^{4}$, ismarmiaty@universitasbumigora.ac.id ${ }^{5}$ \\ 1,2,3,4,5 Universitas Bumigora
}

\begin{abstract}
Article History:
Received: $19-11-2021$

Revised: 11-01-2022

Accepted: 17-01-2022
\end{abstract}

\begin{abstract}
Thinking about computing or Computational Thinking (CT) is one of the problems solving techniques that is very important today to prepare the next generation to be competitive in this digital economy era. This skill teaches students how to think the way scientists think, to solve real-world problems. In training or familiarizing children with CT, this can be done by including or adding $C T$ to the learning strategy. The intended strategy can be related to the packaging of the material, the learning media used, or an interesting learning model that can familiarize children with $C T$. The learning media used are expected to help children understand the subject matter. For early childhood, learning media has a vital role in learning. This is because at that age children are still at the stage of learning while playing. On August 6, 2019, Bumigora University signed a charter of cooperation with the coordination of the national committee (National Board Organization (NBO) bebras Indonesia), where for the next 5 (five) years Bumigora University will become a partner in realizing PANDAl students. PANDAl, is the name chosen as the movement to socialize CT, which stands for Pengjar Digital Era Indonesia. The PANDAI Movement training in collaboration with Bumigora University is also the first teacher training to be held in the entire West Nusa Tenggara region, involving approximately 400 elementary and junior high school teachers. Service activities related to Computational Thinking have been carried out. The results of the implementation have been evaluated with the results that most of the teacher participants agreed to apply the results of the training related to Computational Thinking to students and also most of the participants agreed to join the follow-up programs from Bebras. The implementation stage for students is still unable to carry out the service team due to the current pandemic situation, but with the continuation of the activities carried out by the UBG bureau with NBO Bebras. It is hoped that this activity can run continuously and be supported positively by the parties involved.
\end{abstract}

Keywords:

Accompaniment, Computational Thinking, Bebras, PANDAI

\section{Pendahuluan}

Pergeseran kebutuhan dunia industri di abad 21 harus diantisipasi dengan membiasakan pemikiran tingkat tinggi untuk semua tingkatan pendidikan, dimulai dari sekolah dasar. Perkembangan teknologi yang semakin pesat menghasilkan revolusi yang sangat berpengaruh seperti cloud computing dan start-up. Inovasi tersebut perlu ditopang dengan pengetahuan dan keterampilan CT yang mumpuni oleh pra pendidik dan praktisi. Para pakar pendidikan mengemuka kan bahwa budaya belajar di sekolah harus diubah dari sekedar menghafal menjadi menganalisis. Saat ini ada rekognisi yang berkembang di 
seluruh dunia bahwa semua bidang memerlukan sebuah kemampuan prasyarat, yakni berpikir secara logis dan algoritmik, dan menggunakan alat komputasi untuk membuat modeling dan visualisasi data dengan cepat. Kemampuan tersebut dikenal dengan istilah Computational Thinking (CT) (Romadhona, Suprapedi, \& Himawan, 2017).

Pemikiran mengenai komputasi atau Computational Thinking (CT) merupakan salah satu teknik penyelesaian masalah menjadi sangat penting di masa sekarang untuk menyiapkan generasi penerus yang berdaya saing di era ekonomi digital ini. Kecakapan ini mengajarkan siswa bagaimana berpikir seperti cara ilmuwan berpikir, untuk menyelesaikan permasalahan di dunia nyata. Awalnya istilah Computational Thinking atau Berpikir/Pemikiran Komputasi digaungkan oleh Seymour Papert tahun 1980 dalam bukunya yang berjudul "Mindstorm". Ketika itu Papert berfokus pada dua aspek komputasi: pertama, bagaimana menggunakan komputasi untuk menciptakan pengetahuan baru, dan kedua, bagaimana menggunakan komputer untuk meningkatkan pemikiran dan perubahan pola akses ke pengetahuan. Berikutnya J. M. Wing tahun 2010 membawa pendekatan yang dimodifikasi dan perhatian baru pada pemikiran komputasi atau Computational Thinking. Di mana menganggap pemikiran komputasi sebagai keterampilan dasar untuk kemampuan analitis semua orang sama dengan kecakapan dengan membaca, menulis, dan berhitung. Makalah Wing disambut oleh masyarakat di semua tingkatan, terutama di jenjang pendidikan K-12 (SD-SMA), yang sangat bertanggung jawab dan berpengaruh dalam pengembangan kecakapan dan karakter peserta didik. ACM dan PT Edukasi (Satu, n.d.) juga ikut mendukung lahirnya K12 Curriculum Framework, yang saat ini notabene telah diimplementasikan menjadi standar kurikulum untuk sekolah dasar dan menengah negara maju. Standar kurikulum K12 yang dirintis oleh ACM dan CSTA menjadi salah satu aspek yang menjadi target kompetensi dalam kurikulum tersebut. Indonesia sudah mengadaptasi K12 CS Curriculum tersebut untuk diimplementasikan sebagai kurikulum nasional pendidikan dasar dan menengah, yang sudah disahkan pada tanggal 20 Desember 2018 sebagai Peraturan Menteri Pendidikan dan Kebudayaan nomor 37 tahun 2018 sebagai perubahan dari Permendikbud nomor 24 tahun 2016. Dalam peraturan baru tersebut ditetapkan adanya kompetensi inti (KI) dan Kompetensi dasar (KD) pada pelajaran yang ada dalam Kurikulum 2013(K13), untuk tingkat SD/MI, SMP/Mts hingga SMA/MA. Tujuan dari peraturan tersebut adalah untuk mengembangkan kemampuan peserta didik di era digitai. Dan sebagai pendidik (guru) harus mampu menyisipkan dan mengintergrasikan muatan informatikan pada kompetensi dasar mulai jenjang pendidikan dasar hingan pendidikan menengah.

Diketahui berdasarkan data Dinas pendidikan dan Kebudayaan Nusa Tenggara Barat (NTB) Satu Data, Angka putus sekolah tahun ajaran 2019/2020 Pada jenjang https://journal.universitasbumigora.ac.id/index.php/ADMA 
pendidikan ( SD, SMP, SMK, SMA) Kabupaten Lombok timur tercatat sebagai kabupaten/Kota dengan angka putus sekolah tertinggi di Nusa Tenggara Barat (BPS Nusa Tenggara Barat, 2021). Dijelaskan lebih detail pada Indeks Pembangunan Manusia Kabupaten Lombok Timur 2020, bahwa hanya penduduk yang berusia 15 tahun ke atas yang hanya memiliki ijazah SD/MI sebanyak 24,55 persen (BPS Lombok Timur, 2020). Oleh karena itu Dinas Pendidikan dan Kebudayaan Lombok Timur saat ini sedang berupaya untuk menangani kondisi ini dengan bantuan dari pemerintah dan lembaga lain seperti UNICEF (Klikntb.com, 2021). Latar belakang ini menjadikan salah satu indikator bagi Biro Bebras Universitas Bumigora melakukan kegiatan pedampingan bagi tenaga pendidik bagaimana menyisipkan konsep CT dalam mata pelajaran mulai dari jenjang SD hingga SMP.

Biro Bebras Universitas Bumigora pada tanggal 6 Agustus 2019 menandatangani piagram kerja sama dengan koordinasi komite nasional (National Board Organization (NBO) bebras Indonesia), dimana untuk 5 (lima) tahun kedepan Universitas Bumigora menjadi mitra dalam mewujudkan siswa PANDAI. PANDAI adalah nama yang dipilih sebagai gerakan mensosialisasikan CT yang merupakan singkatan dari Pengajar Era Digital Indonesia. Pelatihan gerakan PANDAI yang berkerjasama dengan Universitas Bumigora ini juga menjadi pelatihan guru pertama yang akan dilaksanakan di suluruh wilayah Nusa Tenggara Barat, dengan akan melibatkan kurang lebih 480 guru diseluruh pulau Lombok. Dalam kegiatannya biro Bebras UBG mensosialisasikan dan mengimplementasikan pemikiran CT ke dalam mata pelajarannya sehingga siswa dapat membangun kemampuan berpikir kritis dan kreatif, khususnya berpikir komputasional" ungkap Ibu Kartarina, M.Kom sebagai koordinator Bebras Biro Universitas Bumigora.

Salah satu program biro bebras UBG adalah kegiatan pendampingan dalam pembuatan soal berbasis CT beserta implementasi pembahasan soal tersebut dikelas. Tujuan dari kegiatan ini adalah siswa lebih aktif bekerja sendiri dalam memecahkan soal sehingga membangun karakter siswa untuk lebih kritis, dan pendidik disini hanya berperan sebagai fasilitator saja. kemampuan problem solving yang dilakukan oleh siswa adalah bentuk dari konsep dasar dalam pelajaran informatika yang lebih bersifat keilmuan (Pertiwi \& Pertiwi, 2020). Melatih dan membiasakan CT kepada siswa, bisa dilakukan dengan cara menyisipkan/menambahkan CT ke dalam strategi pembelajaran. Strategi yang dimaksudkan bisa terkait dengan pengemasan materi, media pembelajaran yang digunakan, atau model pembelajaran yang menarik dan bisa membiasakan CT kepada siswa. Media pembelajaran yang digunakan diharapkan dapat membantu anak dalam memahami materi pelajaran. Untuk anak usia dini, media pembelajaran memiliki peran vital dalam pembelajaran. Hal ini dikarenakan pada usia tersebut anak masih pada tahap 
belajar sambil bermain (Maharani, Nusantara, As'ari, \& Qohar, 2020). Tantangan memberikan ilmu pengetahuan semakin teruji dengan adanya pandemi dimana dampak terburuk dari pandemi Covid-19 adalah dengan mengharuskan pelaksanaan pembelajaran jarak jauh. Salah satu pelaksanaan pembelajaran jarak jauh yaitu pembelajaran mandiri. Para pendidik sebagai punggawa pendidikan dituntut untuk mampu menguasai media pembelajaran sebagai sarana mempermudah proses pembelajaran mandiri di masa pandemi Covid-19 untuk mewujudkan merdeka belajar siswa. Konsep "Merdeka Belajar" memberikan keleluasaan bagi pendidikan untuk menciptakan dan menerapkan metode pembelajaran yang sesuai dengan kurikulum dan karakteristik siswa. Selain itu, siswa diberi kebebasan untuk berinovasi, belajar dengan mandiri, dan kreatif (Octalia, Rizal, \& Siswandari, 2021).

\section{Metode}

Pelaksanaan kegiatan pengabdian ini terdiri dari dua kegiatan utama yaitu kegiatan sosialisasi Computational Thinking dan kegiatan pelatihan Computational Thinking kepada guru-guru peserta. Metode pelaksanaan yang dilakukan terdiri dari beberapa tahap antara lain:

(a) Perencanaan, (b) Persiapan dan (c) Sosialisasi dan Pelatihan, dan (d) Evaluasi. Urutan pelaksanaan tahapan tersebut dapat dilihat pada Gambar 1.

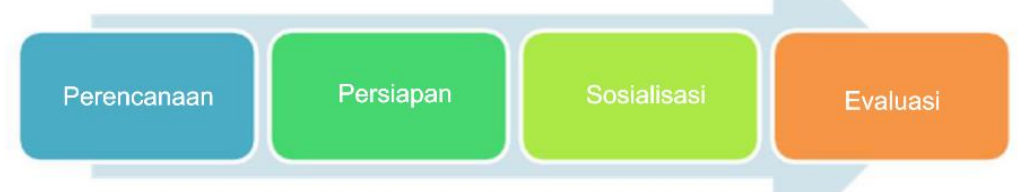

Gambar 1. Tahapan pelaksanaan gerakan pandai bebras

1). Tahap Pertama : Perencanaan

Pada tahap ini team pengabdi berkordinasi dengan pihak dinas Pendidikan setempat untuk mendapatkan ijin penyelenggaraan dan meminta kesediaan untuk dapat membantu dalam mengundang guru-guru tingkat SD dan SMP. Selain itu pada tahap ini, team juga berkordinasi berkaitan sarana dan prasarana saat sosialisasi dan pelatihan, setelah itu Langkah selanjutnya adalah berkordinasi berkaitan waktu yang bisa digunakan untuk melakukan pelatihan, dan menentukan dosen pendamping yang bisa untuk mendampingi peserta pada saat pelatihan pembuatan soal dan mengevaluasi para peserta setelah pelatihan.

2). Tahap Kedua : Persiapan

https://journal.universitasbumigora.ac.id/index.php/ADMA

E-ISSN: 2723-7370 
Pada tahap ini tim pengabdi melakukan koordinasi untuk mempersiapkan contoh soal, materi dan pembagian tim. Pada tahap ini latihan soal yang dibuat di uji coba terlebih dahulu dengan seluruh team pengbadi.

3). Tahap Ketiga : Sosialisasi dan Pelatihan

Tahap sosialisasi merupakan tahap dimana team pengabdi berangkat kelokasi untuk melakukan pelatihan, kegiatan ini dilaksanakan selama 2 hari, dimana hari pertama adalah untuk guru-guru tingkat SD sedangkan hari kedua adalah untuk guru-guru tingkat SMP. Berikut adalah urutan kegiatan yang terselenggara.

Tabel 1. Jadwal kegiatan

\begin{tabular}{|c|c|c|c|}
\hline No & Pukul & Agenda & Keterangan \\
\hline 01 & $09.00-09.30$ & $\begin{array}{c}\text { Pembukaan Pelatihan CT untuk } \\
\text { Guru Registrasi dan } \\
\text { Pengisian Kuesioner pra } \\
\text { kegiatan }\end{array}$ & Inaugurasi guru Peserta Pelatihan \\
\hline 02 & $09.30-10.15$ & Paparan Mengenai CT for all & $\begin{array}{c}\text { Penyampaian materi CT kepada peserta } \\
\text { pelatihan }\end{array}$ \\
\hline 03 & $10.15-10.45$ & $\begin{array}{l}\text { Pengenalan Bebras } \\
\text { Computational Thinking }\end{array}$ & $\begin{array}{c}\text { Pengenalan organisasi dan materinya } \\
\text { kenal CT dari Pemrograman Block Visual } \\
\text { dan Scratch Menggunakan tools seperti } \\
\text { Blockly, } \\
\text { Apps Inventor, Alice. Penyampaian } \\
\text { materi pendaftaran di akun latihan dan } \\
\text { materi soal latihan } \\
\end{array}$ \\
\hline 04 & $10.45-11.30$ & $\begin{array}{c}\text { Computational Thinking dalam } \\
\text { Mapel dan Implementasi dalam } \\
\text { Mapel }\end{array}$ & $\begin{array}{c}\text { Menerapkan Computational Thinking } \\
\text { dalam mapel Contoh soal gerakan pandai } \\
\text { ditujukan untuk guru dan contoh soal } \\
\text { BEBRAS ditujukan untuk siswa }\end{array}$ \\
\hline 05 & $11.30-12.00$ & $\begin{array}{l}\text { Pembagian Kelompok dan } \\
\text { Materi Soal untuk Latihan Guru }\end{array}$ & $\begin{array}{c}\text { Menerapkan Computational Thinking } \\
\text { dan hots dalam mapel Contoh soal gerakan } \\
\text { pandai ditujukan untuk guru dan contoh } \\
\text { soal BEBRAS ditujukan untuk siswa. }\end{array}$ \\
\hline 06 & $12.00-13.00$ & Ishoma & \\
\hline 07 & $13.00-16.00$ & Proses pembuatan Soal & $\begin{array}{c}\text { Setiap kelompok diberikan kesempatan } \\
\text { untuk menyempurnakan soal yang } \\
\text { diberikan dan kemudian dapat } \\
\text { dipresentasikan sekaligus diskusi Bersama } \\
\text { berkaitan kekurangan demi } \\
\text { penyempurnaan soal-soal yang dibuat }\end{array}$ \\
\hline 08 & $16.30-18.00$ & Penutupan & $\begin{array}{l}\text { a. Penjelasan mengenai proses } \\
\text { pendampingan saat implementasi ke } \\
\text { siswa-siswa di sekolah }\end{array}$ \\
\hline
\end{tabular}




\section{4) Tahap Keempat : Evaluasi}

Untuk Tahap ini akan disesuaikan dengan kondisi dilapangan. Hal ini dikarenakan situasi pandemic Covid-19 sehingga sistem tatap muka (luring) pada proses belajarmengajar telah ditiadakan. Sehingga Evaluasi akan dilakukan melalui daring dimana setiap guru diberikan hak akses pada classroom sehingga bisa melaporkan kegiatan implementasi yang sudah dilakukan.

\section{Pembahasan}

\section{Perencanaan}

Pada tahapan Ini, tim yang dipimpin oleh kepala bebras biro mengadakan rapat koordinasi untuk mempersiapkan anggota dan surat-surat agar dapat di gunakan sebagai bahan pengurusan ijin pada dinas setempat. Selain itu juga pada tahapan ini dipersiapkan roundown acara terutama yang berkaitan dengan langkah-langkah sosialisasi dan pelatihan yang akan dilaksanakan. Hal yang terpenting yang harus diprioritaskan adalah kapan acara tersebut dapat terselenggara dan bagaimana sistematis pelaksanaannya, karena situasi yang tidak memungkinkan akibat pandemi sehingga jumlah peserta harus dibatasi sesuai dengan ketentuan social distancing.

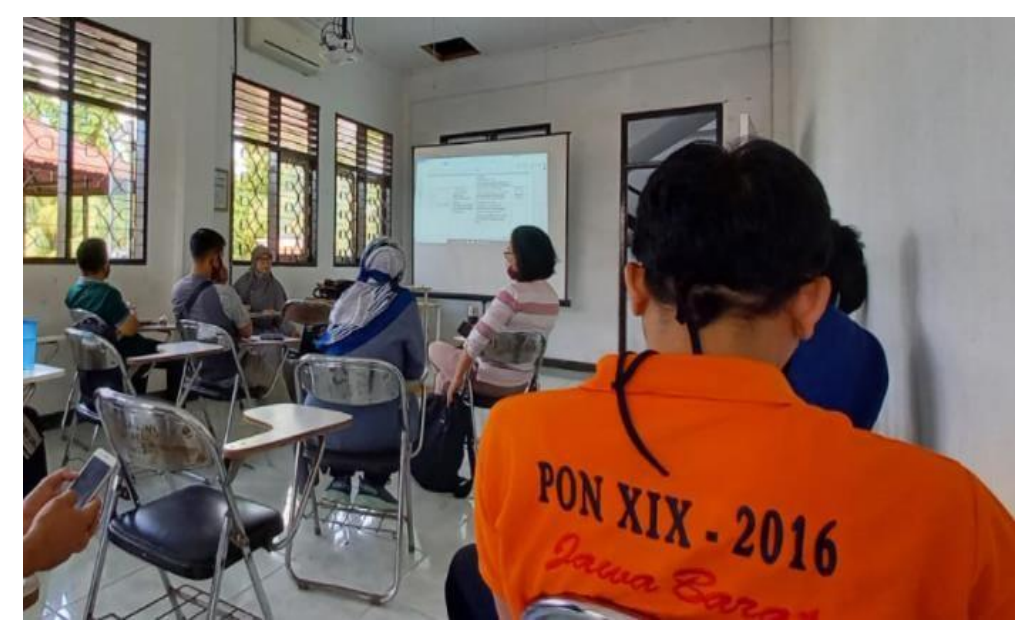

Gambar 2. Rapat koordinasi sebelum berangkat ke dinas

Rapat koordinasi dihadiri oleh dosen-dosen Universitas Bumigora yang berasal dari berbagai Jurusan. Kemudian di tunjuk siapa yang akan berangkat untuk proses permintaan ijin pelaksanaan dan ijin peminjaman tempat.

\section{Persiapan}

Agar nantinya pada saat sosialisasi dan pelatihan tidak mengalami banyak kendala dan dapat berjalan dengan lancar (sukses) untuk itu team pengabdi melakukan uji coba dikelas dengan berdiskusi dan mempraktekkan hal-hal apa saja yang akan dijelaskan ke para guru. Mulai dari proses pembuatan soal, menjabarkan bagaimana soal CT yang mengandung HOTS dan apakah sosl-soal tersebut ada kandungan 
mata pelajaran yang lain selain muatan pelajaran utama.

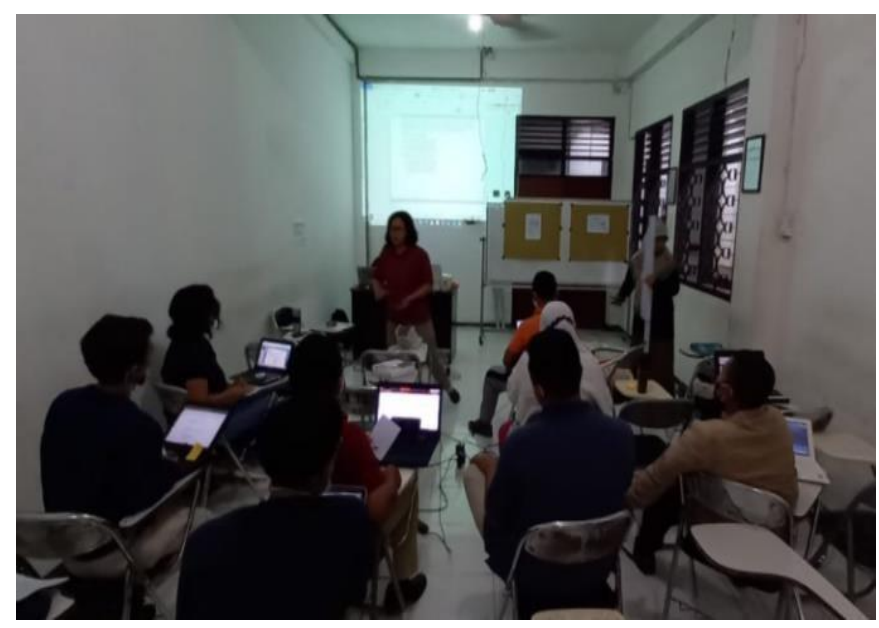

Gambar 3. Uji coba sosialisasi di kelas

\section{Sosialisasi dan Pelatihan}

Pada Bulan April Tepatnya pada tanggal 5 April 2021, Team Bebras Biro UBG berangkat menuju ke Lombok Timur untuk mengadakan kegiatan pelatihan kepada guru-guru tingkat SD dan SMP. Sebelum acara dimulai, para guru diminta untuk mengisi formulir untuk dimasukkan datanya dalam classroom. Setelah seluruh peserta teregistrasi, acara kemudian dibuka oleh ketua Yayasan Darul Abror NW, Bapak TGH Zainul Mukhlis, MT. Kemudian acara selanjutnya diserahkan ke Tim pengabdi.

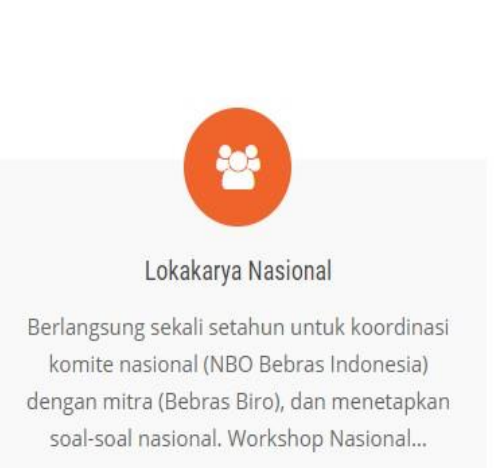

\section{Kegiatan Bebras Indonesia}
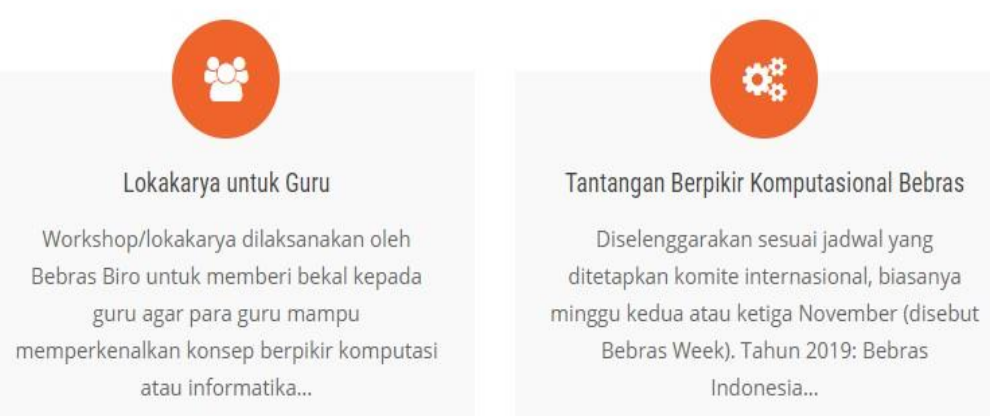

Gambar 4. Jenis kegiatan sosialisasi dan pelatihan

Pada Tahap awal, Ketua Biro yaitu Ibu Kartarina Augustine, M.Kom yang menjelaskan secara singkat mengenai pendidik Bebras dan kegiatan apa saja yang diberikan. Yang mana Gerakan ini pada mulanya merupakan aktivitas ekstra kurikuler yang mengedukasi kemampuan problem solving dalam informatika. Siswa peserta akan mengikuti kompetisi bebras di bawah pendidikan guru, yang dapat mengintegrasikan tantangan tersebut dalam aktivitas mengajar guru. Kompetisi ini dilakukan setiap tahun secara online. Seiring berjalannya waktu terdapat modifikasi dimana tidak semuanya 
ADMA

Jurnal Pengabdian dan Pemberdayaan Masyarakat

berkaitan dengan computer, tapi bisa juga masuk ke rumpun ilmu yang lain baik itu eksataaupun social. Tujuan utamanya adalah untuk mempromosikan informatika dan berpikir komputasi kepada para guru dan anak-anak muda khususnya, di kalangan pengambil keputusan di bidangpendidikan, dan masyarakat luas.

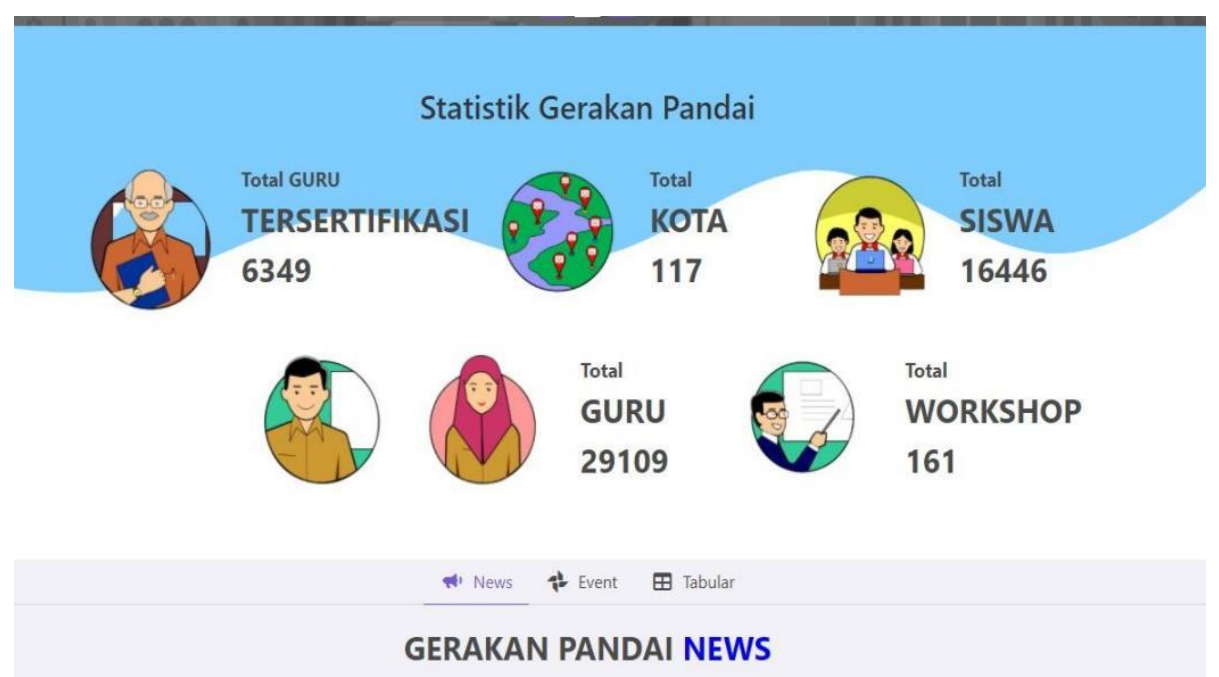

Gambar 5. Data statistik gerakan pandai

Tahap Selanjutnya adalah penjabaran atau sosialisasi contoh soal seperti apa yang bermuatan CT yang mana soal yang diberikan ke siswa tidak hanya bermuatan CT tapi harapannya adalah soal-soal tersebut dapat menumbuhkan kreatifitas siswa, membuat para siswa lebih berprikis kritis dan lebih komunikatif.

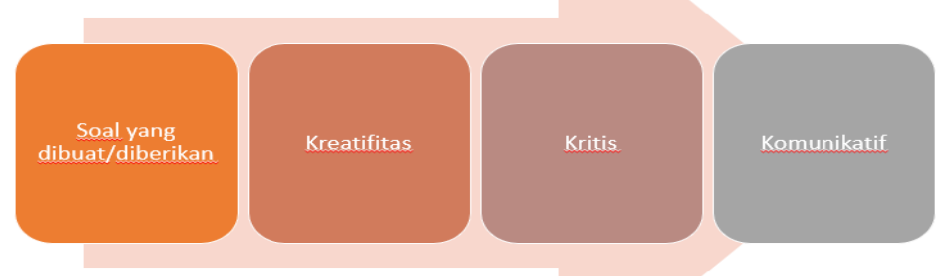

Gambar 6. Penjabaran atau sosialisasi contoh soal 

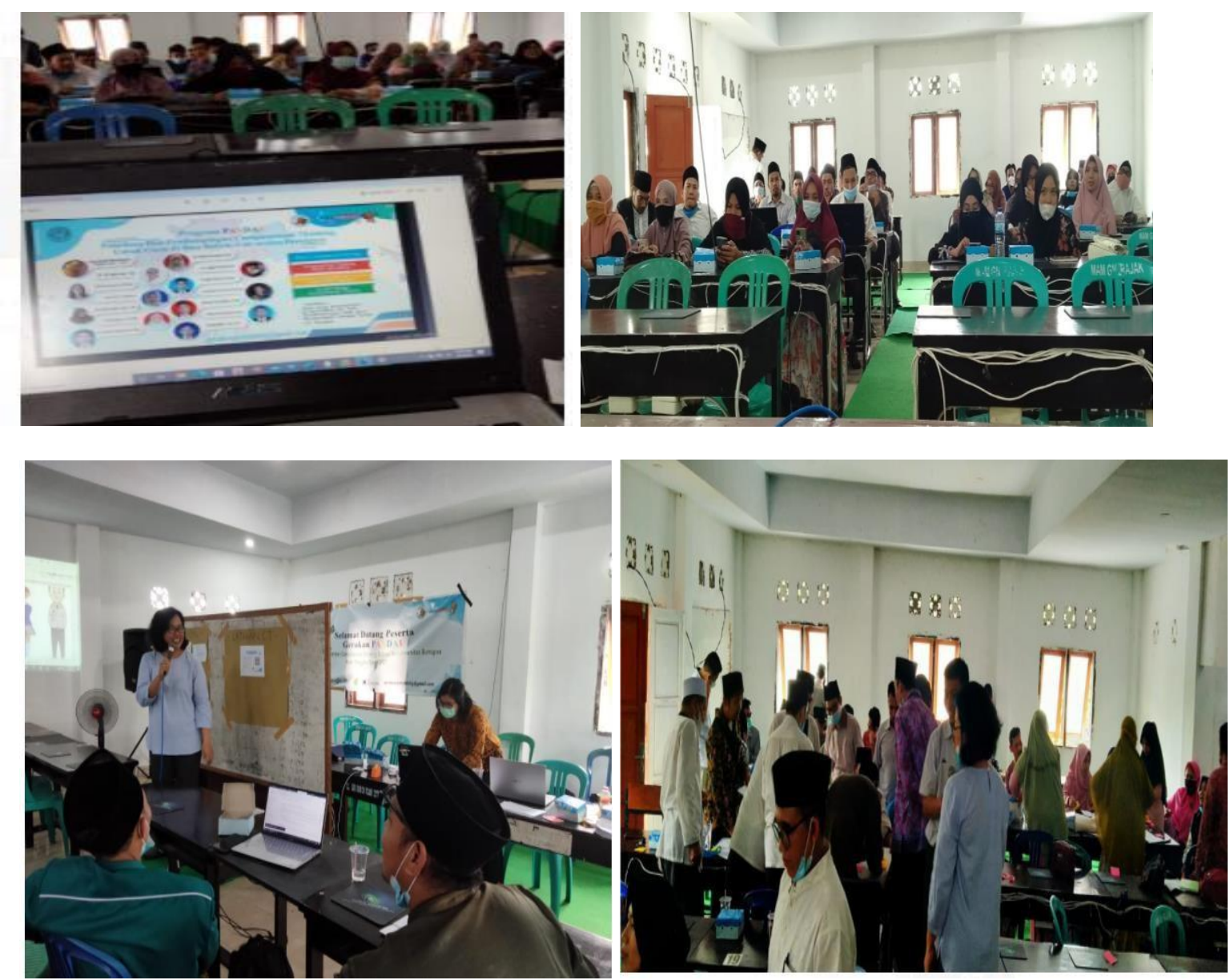

Gambar 7. Sosialisasi contoh soal CT yang bermuatan HOTS

Setelah dilakukan sosialisasi, Langkah selanjutnya adalah para guru di coba latihan membuat soal baru yang bermuatan CT, dimana para guru dibagi menjadi 5 kelompok yang masing-masing kelompok terdiri atas 10 sampai 11 orang. Team pengabdi membebaskan para guru untuk berkreasi dengan mata pelajaran yang ingin di buat, namun hal utama yang dipenuhi adalah soal yang dibuat adalah soal yang harus mengandung HOTS. Semakin banyak kandungan Mapel (Mata pelajaran) semakin bagus nilai yang akan diberikan.

Di dalam 2 jam waktu pengerjaan akan dilihat kemmapuan para guru untuk bekerja sama, berkoordinasi, berkomunikasi dan saling membantu. Setelah soal selesai dibuat di alat peraga yang telah diberikan, Langkah selanjutnya adalah para peserta mempresentasikan soal yang telah dibuat untuk kemudian diberikan nilai oleh peserta lain dan dari pihak dosen pendamping. 

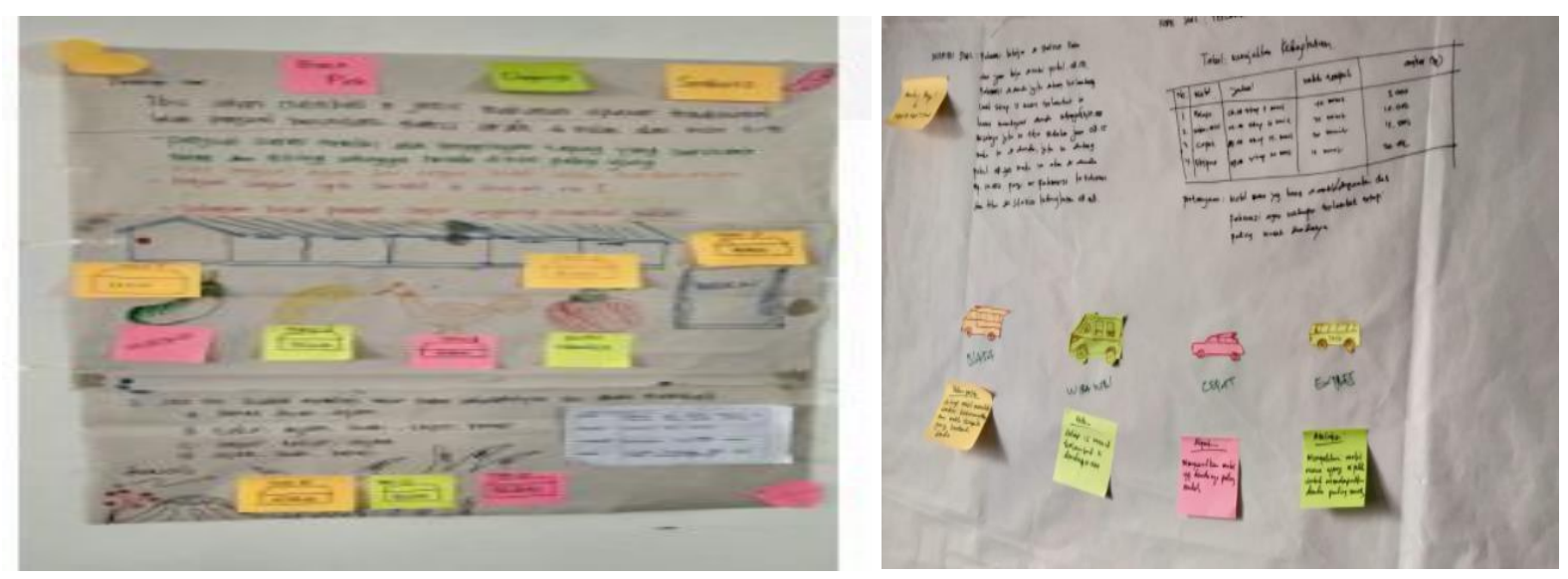

Gambar 6. Foto soal-soal yang dibuat peserta yang ditempel pada alat peraga

\section{Evaluasi}

Setelah diadakan sosialisasi dan pelatihan, Langkah selanjutnya adalah memberikan evaluasi dengan melihat sejauh mana soal-soal yang telah dibuat oleh para guru dapat dipraktekkan ke para siswa. Namun dikarenakan situasi yang tidak memungkinkan sekolah tatap muka tidak dijinkan sehingga kebanyakan sekolah dilakukan secara daring. Hasil evaluasi dari pembuatan soal yang dikerjakan oleh guru pendidik, sudah bisa menyisipkan pemikiran CT pada soal latihan siswa. Pada soal terdapat konsep abstraksi, dekomposisi, pengenalan pola dan algoritma. Pada konsep abstraksi soal yang diberikan berupa cerita dan siswa bisa mengabstraksi cerita tersebut menjadi suatu permasalah utama. Tahap dekomposisi, siswa mampu mengidentifikasi apa saja yang langkah yang harus siswa lakukan untuk memecahkan permasalahan tersebut. Selanjutnya dari soal latihan yang diberikan siswa mampu mengenali pola yang terkandung, dan diakhir siswa secara tidak langsung mampu menyusun algoritma tahapan yang harus dilakukan untuk memperoleh jawaban dari soal latihan yang diberikan guru. Soal yang dihasilkan guru SD dan SMP ada 5 macam pertanyaan yang juga merupakan soal HOTS, dimana menitikberatkan soal pada kemampuan menalar siswa dan kemampuan menganalisa ide dan informasi yang terkandung dalam soal. Dengan begitu siswa secara tidak langsung melatih nalarnya, membiasakan, dan membentuk pola pikir tingkat tinggi.

\section{Kesimpulan}

Kegiatan pengabdian terkait dengan Computational Thinking telah dilaksanakan. Hasil pelaksanaan telah dievaluasi dengan hasil bahwa sebagian besar peserta guru setuju untuk menerapkan hasil pelatihan terkait Computational Thinking kepada siswa dan juga sebagian besar peserta menyatakan setuju untuk bergabung 
pad program-program lanjutan dari Bebras. Tahap implementasi ke siswa masih belum bisa team pengabdi laksanakan dikarena situasi pandemic saat ini namun dengannya keberlanjutan kegiatan yang biro UBG dangan NBO Bebras Diharapkan kegiatan ini dapat berjalan secara berkesinambungan dan didukung secara positif oleh pihak-pihak yang terlibat.

\section{Ucapan Terimakasih}

Terimakasih kepada Kepala LPPM Universitas Bumigora yang telah memberikan izin untuk melakukan PKM. Kepada Bebras Indonesia yang memberikan kepercayaan kepada Dosen untuk menjadi Biro Bebras. Kepada tim relawan dosen dan mahasiswa yang sekaligus menjadi tim pengabdian masyarakat.

\section{Daftar Pustaka}

BPS Lombok Timur. (2020). INDEKS PEMBANGUNAN MANUSIA KABUPATEN LOMBOK TIMUR. Lombok Timur. Retrieved from https://lomboktimurkab.bps.go.id/publikasi.html

BPS Nusa Tenggara Barat. (2021). PROVINSI NUSA TENGGARA BARAT DALAM ANGKA 2021. Nusa Tenggara $\quad$ Barat. $\quad$ Retrieved from https://ntb.bps.go.id/publication/2021/02/26/2031d130d7ffc9ed4b9b47ce/provinsi-nusatenggara-barat-dalam-angka-2021.html

Klikntb.com. (2021). Lombok Timur Angka Putus Sekolah Tertinggi di NTB, Ini Jawaban DIKBUD. Klik NTB, pp. 1-7. Retrieved from https://www.klikntb.com/lombok-timur-angka-putus-sekolahtertinggi-di-ntb-ini-jawaban-dikbud/

Maharani, S., Nusantara, T., As'ari, A. R., \& Qohar, A. (2020). Computational Thinking: Media Pembelajaran CSK (CT-Sheet for Kids) dalam Matematika PAUD. Jurnal Obsesi: Jurnal Pendidikan Anak Usia Dini, 5(1), 975-984. https://doi.org/10.31004/obsesi.v5i1.769

Octalia, R. P., Rizal, N., \& Siswandari, H. (2021). Pengembangan Media Pembelajaran Digital Berbasis Game Challenges untuk Meningkatkan Computational Thinking dalam Pembelajaran Mandiri sebagai Upaya Mewujudkan Merdeka Belajar, 149-166.

Pertiwi, A., \& Pertiwi, A. (2020). Konsep Informatika Dan Computational Thinking Di Dalam Kurikulum Sekolah Dasar, Menengah, Dan Atas. Abdimasku: Jurnal Pengabdian Masyarakat, 3(3), 146. https://doi.org/10.33633/ja.v3i3.53

Romadhona, A., Suprapedi, \& Himawan, H. (2017). Prediksi Kelulusan Mahasiswa Tepat Waktu Berdasarkan Usia, Jenis Kelamin, Dan Indeks Prestasi Menggunakan Algoritma Decision Tree. Jurnal Teknologi Informasi, 13, 69-83. 
